\title{
Tok Pulau Manis: Pioneer of Fiqh writings in the Malay Peninsular
}

\author{
Zurita Mohd Yusoff ${ }^{1}$, Hasanulddin Mohd ${ }^{1}$, Abdul Karim Ali ${ }^{2}$, Engku Ibrahim Engku Wok ${ }^{1}$, Noor Anida Awang ${ }^{1}$ \\ $\&$ Syed Mohd Hafiz Syed Omar ${ }^{1}$ \\ ${ }^{1}$ Faculty of Islamic Contemporary Studies, Universiti Sultan Zainal Abidin (UniSZA), Terengganu, Malaysia \\ ${ }^{2}$ Academy of Islamic Studies, University of Malaya, Kuala Lumpur, Malaysia \\ Correspondence: Zurita Mohd Yusoff, Centre for Syariah Studies, Faculty of Islamic Contemporary Studies, \\ Universiti Sultan Zainal Abidin (UniSZA), Terengganu, Malaysia. Tel: 60-013-983-8957. E-mail: \\ zurita@unisza.edu.my
}

Received: September 11, 2014 Accepted: September 26, 2014 Online Published: November 29, 2014

doi:10.5539/ass.v11n1p84 URL: http://dx.doi.org/10.5539/ass.v11n1p84

\begin{abstract}
The proselytising of Islam in the Malay Peninsular depended on the earnestness of the classical Islamic scholars. The spreading of Islam was done through religious talks, Islamic studies classes, and through their writings. Syeikh Abdul Malik bin Abdullah, also known as Tok Pulau Manis is one of the classical Islamic scholars that was born in the state of Terengganu, which was active in producing religious books especially in the field of fiqh and tasawwuf. However, most of the recent generations are not aware of his legacy and contributions in the spreading of Islam. Therefore, this article attempts to study his life and academic background, and highlights his contribution as one of the earliest classical Islamic scholars that produced fiqh writings in the Malay Peninsula. The result of this study finds that Tok Pulau Manis is an esteemed scholar, which was hold in high regard by the dignitaries including the Sultan Zainal Abidin I himself. His involvement in producing fiqh writings in Jāwī during the 17 and $18^{\text {th }}$ century had placed him as one of the pioneers of the fiqh writing in the Malay Peninsula.
\end{abstract}

Keywords: Tok Pulau Manis, pioneer, Fiqh writings, Malay Peninsula

\section{Introduction}

Islam has been found having its root in the Malay Archipelago since 7AD with the emigration of Arabs to Java. In the Malaysian Peninsula (formerly known as Malay Peninsula), the spread of Islam has begun since 14AD. The discovery of a stone tablet in Terengganu in 1303AD has proved that the rulers and their subjects alike in the Malay Peninsula have practised the Shari'ah (Islamic laws) at that time. Next, Islam is becoming more popular in the Malay Archipelago with the intensive efforts by Islamic scholars, both locals and internationals who came from cities such as Baghdad, Egypt, Yemen and Saudi Arabia. These Islamic scholars not only preach orally, but also produced writings that encompass wide-ranging fields of Islamic knowledge. Religious-based writings in the Malay Peninsula peaked during the $17^{\text {th }}$ century following the intensive missionary scene that was happening in the Malay Archipelago, which centred in Aceh (Mahayudin, 2000).

Fiqh was one of the important fields to be learned and practiced by Muslims. Since the coming of Islam during the $17^{\text {th }}$ century, classical fiqh writings in Malay were hard to come by and making it hard for the Malays to acquire religious-based writings in their native language. Apart from the lectures that were given by Islamic scholars at that time, Muslims need religious books in Malay as reference points. In dealing with the shortage of religious references in Malay, Tok Pulau Manis has produced his writings in Malay.

\section{Method}

For thid study, the data was collected from various sources namely classical books, hadith, manuscripts of Kitab al-Kifōyah and also article journals. To get the data about the background of Tok Pulau Manis, we use an interview method. We have interviewed Tuan Guru Sheikh Tok Ku Ibrahim Mohamad, Principal of Pondok Pulau Manis, at Kampung Pulau Manis, Kuala Terengganu and Ismail bin Embong, who is one of the $8^{\text {th }}$ generation of Syeikh Abdul Malik bin Abdullah. We analyse the data by inductive and deductive methods. We then coded the data into specific themes as described below. 


\section{Birth and Demise of Tok Pulau Manis}

Tok Pulau Manis is an Islamic scholar from Terengganu whose lineage that can be traced to scholars that hailed from Baghdad. According to the inscription on his grave in Kampung Pulau Manis, Kuala Terengganu, Tok Pulau Manis was born in the year 1089H/1678AD and died 1149H/1736AD. These dates show that Tok Pulau Manis died at the age of 58 years old.

However, there are contradicting facts that show Tok Pulau Manis was born earlier than the indicated date. In one of his writings, there is a note that indicated that he used to study with a renowned scholar Syeikh Ibrahim al-Kurani (c. 1025H/1661M- 1101H/1690M). Taking into account of his stated birth date, he was only 12 years old when his learned teacher passed away (Shafie, 1977). In the researchers' opinion, it is illogical for a 12 year old to have studied in faraway lands such as Aceh and Mecca. Stories narrated by his descendants and few other facts postulated by previous researchers indicate that Tok Pulau Manis was born earlier that the inscribed date on his tombstone (Shafie, 1977, Ibrahim: 15 Januari 2011 dan Mohd Saleh, 1983).

His date of death is also illogical and the agreed upon date by various researchers is in the year of $1149 \mathrm{H} / 1736 \mathrm{AD}$, at the age of circa 86 years old. This fact corroborates with information which states that he passed away in his old age (M.C. ff. Sheppard 1949:11). Narratives from his relatives also seem to corroborate this fact (Shafie, 1984).

\section{Tok Pulau Manis' Studies}

Tok Pulau Manis's studies can be categorised into two stages; studies in Java and Aceh, and in Mecca and Medina. His studies in Java and Aceh can be described as elementary stages while in the latter places can be described as advanced stages. His first teacher was his own father, Syeikh Abdullah bin Syeikh Abdul Qahar. Before migrating to other places, he used to study from the local scholars (Ibrahim, 1999).

He then continued his study in Aceh, which at that time was the centre of knowledge in the Malay Archipelago, before continuing his study in Mecca. Due to its popularity and status, Aceh is also known as 'Serambi Mekah (Note 1)' (Ibrahim, 1999). Tok Pulau Manis was known as an outstanding student of the renowned Syeikh Abdul Raūf Singkel (Azra, 1994). His study in Aceh was later proved by his hand-written copy of Tafsiran Baidawī that was written in Malay by Syeikh Abdul Raūf Singkel (Shafie, 1989).

Syeikh Abdul Raūf Singkel was a student of two famous scholars in Mecca, Syeikh Ibrāhīm al-Kurānī dan Syeikh Aḥmad al-Qusaisyī. Syeikh Abdul Raūf Singkel at that time was a religious advisor to the Palace, which was a learned scholar of hadith, fiqh, ușūl ad-dīn, nahu, saraf, tafsir, tașawwuf, and a leader of Țarīqah (Note 2) Shatariyyah. Contend that one of his students, Abdul Malik bin Abdullah is well-versed in hadith, tafsir, nahu, saraf, fiqh and tașawwuf, Syeikh Abdul Raūf Singkel was then agreed to induct him into Țarīqah Shatariyyah (Shafie, 1999).

Tok Pulau Manis has immigrated to Mecca circa 1680s during his 30s. To date, there is no official account on the first Malay to have studied there. Nevertheless, past studies seem to indicate that Tok Pulau Manis is one of the pioneers. He then returned home and significantly contributes to Islam just like scholars such as Muhammad Arsyad al-Banjari, Nawawi al-Bantani and Syeikh Daud al-Fatani (Redzuan, 1998).

Among the three fields of aqidah, tașawwuf, and fiqh, Tok Pulau Manis is certainly an ardent student on tașawwuf. The second most favourite subject is fiqh. His main teacher is Syeikh Ibrāhīm al-Kurānī. His writings seem to have indicated that he relied heavily from the fiqh books such as Daw al-Shama'ah by Syeikh Jalaluddin al-Suyūțī, Munyah Ahl al-Warā' by Syeikh Ahmad al-Qusaishi, Minhaj al-Tālibīn by Imam Nawawī, Tatimmah by Ibn Matūlī, al-Ḥāwī by al-Mawardī and Nihāyah by Imam al-Ramlī (Shafie, 1985).

In the field of ușūl ad-dīn, Tok Pulau Manis had opted for the approach of Imam al-Ash'arī which was adopted by ahl as-sunnah wa al-jamáah (Sunnites). This approach is also adopted by the leaders of Tariqqah Shādhiliyyah namely Abū al-Hassan al-Shadhilī and Abū al-'Abbās al-Mursī (Shafie, 1989). According to his writings, Tok Pulau Manis does not only specialised in the above-mentioned fields, but he also had a deep understanding on other fields such as tafsìr, hadìth, mustalah dan auxiliary fields such as nahu, saraf, balaghah and al-sìrah al-nabawiyyah. His vast knowledge in these disciplines has made him as an esteemed Islamic scholar (Shafie, 1985).

In his 40s, Tok Pulau Manis decided to leave Mecca for his hometown. It is hypothesised that his return was associated with the death of his teacher Syeikh Ibrāhīm al-Kurānī in the year of 1101H/ 1690M. This is because his return coincided with the demise of Syeikh Ibrāhīm al-Kurānī. 


\section{Contributions of Tok Pulau Manis}

Subsequent to his return, he found that the locals were in great need of his knowledge that he had gathered in almost 2 decades of wayfaring to Aceh, Mecca and Medina. Tok Pulau Manis' contributions to the studies of Islam in Terengganu can be categorised into three; namely, the setting up of the pondok (Note 3) system, religious writings, and his capacity as the Palace advisor on matters relating to Islam.

\subsection{Institutionalisation of Pondok System}

Tok Pulau Manis had become a pioneer in the institutionalisation of pondok in Terengganu. He has built his home close to the Kampung Pulau Manis Mosque. The Sultan, along with Tok Pulau Manis have moved their administration and learning centres to Kampung Pulau Manis respectively. The move has made Kampung Pulau Manis as the administrative and spiritual capitals of Terengganu. Not long after that, students from the Malay Peninsula and its neighbouring countries in the Archipelago came to Terengganu to be under his tutelage (Ibrahim, 1999). Besides becoming one of the earliest centre of education, the study area was filled with books, which were used as a teaching and reference tools. He used books that he brought from Mecca, Aceh and some of his own writings (Shafie, 1991).

In summary, it can be deduced that Tok Pulau Manis is one of the classical scholars that was educated in the Middle East and gave significant contributions to his hometown. He mastered various disciplines and authored books in the fields of tașawwuf and fiqh, which became reference books during his time. Further, some of his books are still being printed and used as reference books in the local madrasa and Islamic studies centres. His role as the Palace advisor has eased his teachings of Islam.

\subsection{Tok Pulau Manis' Books}

Tok Pulau Manis has not only acted as the mufti but authored books that were used as teaching tools as well as being reference books by the society at that time. Tok Pulau Manis has actually written few books during his times in Aceh. Nevertheless, those books were mainly reproductions and translations (Shafie, 1984).

With deep knowledge of tașawwuf, Tok Pulau Manis has managed to write a book named Hikam Melayu during his study in Mecca that turned out to be his magnum opus (Ibrahim, 1999). It was a lecture on Matan Hikam by Imām Tāj al-Dīn 'Ațaāillāh al-Sakandary that subscribed to Shādhilī (Shafie, 1984). In the Hikam Melayu, it stated that:

"(And) in fact it has been requested of me by few of my salik brethren to translate to Jawi so as it would be advantageous to the new students, and I consented to do so, with the knowledge made understood by Allah Taala to me, I extended them by means of explication within my kifãyah (general obligation) to those new students and I seek refuge in Allah Subhanahu wa Taala's perfection and I hope to reap the reward bequeathed to the students of knowledge, in this world and the next with the blessings of Sayyid al-Mursalīn wa ālihī wa șahbihī ajma ‘īn”

The above passage shows Tok Pulau Manis' standing amongst his peers. This book was used as a teaching material in Mecca. Since Mecca during the time was a hub for printing and publishing Islamic studies books, this book was widely copied, printed and disseminated in the Malay Archipelago. This book is still in use in villages and cities alike.

Though Tok Pulau Manis is widely known through his magnum opus - Kitab Hikam Melayu, but he had managed to write three more books on fiqh, i.e. Kitab al-Kifäyah, Risalah al-Naql and Risalah Kayfiyyah Niyyah. Among these three, Kitab al-Kifayah is the most voluminous since it covers the debate on various topics, inter alia, ablution, prayers, burial management, fasting, and tithe payment. Details on these books will be explained further in the following sections.

\subsection{Appointment as the Royal Advisor to the Sultan of Terengganu}

Since his return to Terengganu, Tok Pulau Manis has been appointed as the royal advisor to the Sultan of Terengganu. He has the capacity of issuing fatwas relating to Islamic laws and its subsequent implementation. For instance, he wrote a book called Risalah al-Naql to clarify on the issue of Friday prayer's congregation. It was because the number of congregators was insufficient to initiate such prayer. Risalah al-Naql was written by him to expound the opinions of venerable scholars on such issues (Shafie, 1989).

The narrative of Tok Pulau Manis' exploits as a mufti is also being passed down by his descendants from one generation to the next. According to Dato' Haji Ambak, Tok Pulau Manis is a faqīh (an expert in fiqh), șūfī, and arif. It was proved by the fact that Kitab Hikam was not merely translated by him, but it was arranged and analysed according to the reality of the time (Dato' Haji Ambak Bin Ismail, $1^{\text {st }}$ February, 2011). Haji Ismail Bin 
Embong asserts that Tok Pulau Manis is an 'ulamā' which was ahead of his time. During a 'Maal Hijrah' conference in Terengganu, a resolution was tabled to immortalise his name as a historic one. Finally, a secondary Islamic boarding school was renamed into 'Sekolah Menengah Kebangsaan Agama Tok Pulau Manis'.

\section{Fiqh Books by Tok Pulau Manis}

Tok Pulau Manis is one of the local scholars who have written books on fiqh in the Malay Peninsula. He was very keen on the subject because of the scarcity of reference book in his native language during late $17^{\text {th }}$ and early $18^{\text {th }}$ century. His books was used extensively by the locals residents and by people outside Terengganu as well.

There are at least three books on fiqh that can be attributed to Tok Pulau Manis, i.e. Kitab al-Kifäyah, Risalah al-Naql and Risalah Kayfiyyah Niyyah. Tok Pulau Manis had written extensively since his days in Aceh but those books were mainly re-copies and translation in nature (Shafie, 1984).

\subsection{Kitab al-Kifāyah}

The second most important work by Tok Pulau Manis is Kitab al-Kifāyah that discusses uṣūl ad-dīn and fiqh. It discusses issues on 'aqīdah, and fiqh rulings on taharah, șalāt, fasting, zakat, animals that are halāl, and harām for consumption, and burial management (Malik, n. d.). This book was written with the locals in mind and is no longer in print. The researcher was unable to locate other version except for two books, which are in the custodian of National Library of Malaysia and Islamic Arts Museum Malaysia.

The literal translation of the word "kifäyah" means 'enough'. Therefore, the title itself connotes the essence of the book-imperative and sufficient as a 'basic building block' for a Muslim. Kitab al-Kifäyah is a book that covers the comprehensive debates on the fundamental knowledge of a Muslim individual or otherwise known as fardh al-'ayn.

Upon further examination on these Kitab al-Kifäyah manuscripts by the researchers found no indication of the official date of when the book was written. However, according to Ismail Che Daud (2012), the book was completed on Thursday $1138 \mathrm{H} / 27^{\text {th }}$ of June $1726 \mathrm{AD}$.

As the oldest fiqh book that was written in Terengganu and amongst one of the oldest in the Malay Peninsula after Kitab Sirät al-Mustaqìm (Zurita, 2014), the researchers opine that Kitab al-Kifäyah was written to disseminate basic knowledge of the religion to the masses of that time, inclusive of the tawhīd and fiqh aspects. Since the knowledge of the Muslims at that time was rather limited and Tok Pulau Manis was one of the pioneering students at Mecca (Mohammad, 1998), indirectly contributes Kitab al-Kifāyah's importance as a teaching tool in the proselytising Islam.

During late $17^{\text {th }}$ and early $18^{\text {th }}$ century, religious books that discuss on fiqh was rather limited (Shafie, 1985). The only book that was widely used at that time was written by scholars from Aceh and one of the most revered books was Kitab Sirāt tal-Mustaqīm that was written by Syeikh Nūr al-Dīn al-Rānirī (1054H/1664M) (Abdul Kadir, 1996). The researchers also believe that there were no other scholars in Terengganu or other states for that matter, which has managed to write fiqh books except for Tok Pulau Manis.

The second most important book in this part of the world after Sirāt al-Mustaqìm is Mir'āt al-Tullāb li Ma'rifah al-Sharīah al-Malik al-Wahhāb which was written by Syeikh Abdul Ra'ūf al-Fanșurī (1024H/1615M-1105H/1693M). Then, came Kitab Sabīl al-Muhtadīn by which was written by Syeikh Muhammad Arshad al-Banjari in 1195H/1779M (Kadir, 1996). Between these two books, Tok Pulau Manis produced Kitab al-Kifäyah. The book was seen to fill the void caused by the lack of reference materials especially on fiqh.

Besides that, Kitab al-Kifäyah was used as the textbook or part of the syllabus by the students of Tok Pulau Manis' pondok system. Shafie Abu Bakar mentions the following in his research:

"This book was written for the teaching purposes in the learning centre founded by the scholar (Tok Pulau Manis) as well as for reference purposes by the locals." (Shafie, 1985)

Kitab al-Kifäyah discusses aqidah and fiqh aspect of the religion. However, discussion on aqidah covers only $30 \%$ out of the total content while the rest of the book is dominated by the discussion on fiqh. This book can be divided into 12 chapters (also known as kitab). It includes Pillars of Faith Book, Pillars of Islam Book, Fiqh Rulings on Human Practices, Things that Invalidate One's Religion, Ablution, Șalāt, Burial Management, Tithe Payment, Fasting, Qurbān, 'Aqīqah, Dhabīhahah, and Dietary Book.

From the above chapters, it is evident that Tok Pulau Manis started his debate by stressing on the 'aqiidah of a Muslim. He values its importance by explicating the issue of aš-šahädatān (the two testimonials) and things that 
nullify them. Once the discussion finishes, the author then proceeds with discussions on fiqh. It was preceded with the discussion on Fiqh Rulings on Human Practices.

Kitab al-Kifãyah was written with extensive reference to the highly referenced books in the Shafie Madhab. Its main reference was Kitab Tuhfat al-Muhtāj Bisyarḥ al-Minhāj by Syeikh al-Islām Shihāb al-Dīn Abū al-'Abbās Aḥmad bin Muhammad bin 'Alī bin Ḥajar al-Haytamī, a faqīh from Egypt. Kitab Tuḥfat is considered as a masterpiece in fiqh and is revered among Shāfi'‘iyyah scholars. Besides that, Tok Pulau Manis also used Kitab Minhāj al-Ṭălibīn Wa Umdah al-Muftīn by Muhyi al-Dīn Abū Zakariyyā Yaḥyā bin Sharf bin Murri al-Hazami al-Shāfi‘ī or popularly known as Imam al-Nawawi.

Another scholar that was mentioned by the author in Kitab al-Kifāyah is Imam al-Ruyānī. Upon further scrutiny on books authored by Imam al-Ruyānī, there is a celebrated book that discusses various topics on fiqh, Baḥr al-Madhhab fi Furū' Madhhab al-Imām al-Shāfi 'ì.

Apart from these three books, there are other books that were used as references but were not recorded in the text. Among the books that share the same facts with al-Kifäyah text are Fath al-Wahhāb Bi Syarh Manhaj al-Tullāb by Imam Abū Zakariyyā al-Anșārī, Sharh al-Waraqāt Li Imām al-Haramain al-Juwain̄̄ by Imam Tāj al-Dīn al-Farāzī, Mughnī al-Muḥtāj Ilā Ma 'rifah Ma āñ̄ Alfāz al-Minhāj by Imam Shams al-Dīn al-Khāțị al-Sharbinī and Al-Mustasfā Min 'Ilm al-Ușül by Imam al-Ghazali.

\subsection{Risâlah al-Naql}

Al-Naql literally means collection or copies. This is attributed to the fact that this book was the author's opinion on the issue of minimum congregators for Juma'ah prayer. It was a culmination of several opinions of scholars on the matter (Shafie, 1985). The book was written as a guideline on issue of the lack of congregators during Friday prayer. The problem was more evident in remote places with small population.

Among the fatwas issues by Tok Pulau Manis in Risalah al-Naql is:

The first qawl (opinion) is that Friday prayer is valid with two males with one being the imam and the other is the congregator, according to Nakhai and Hasan son of Salih and Dawud. The second qawl is that Friday prayer is valid with three men, one being the imam and the other two are its congregators according to Awzai and Abu Thawri of madhab Abu Yusuf."

Risalah al-Naql is a mere 23-pages book. The other available print contains 14-pages. The discrepancies might be due to redundancies and additional comments by Tok Pulau Manis himself (Shafie, 1985). This book was authored by Tok Pulau Manis three years after his return from Mecca and it made substantive reference a book named Daw'u al-Samaah by Syeikh Jalāluddn as-Suyuṭi (849-911H/ 1445-1505AD) (Ibrahim, 1999). His opinion was substantiated by attestation from the imams of four Madhabs in Islam or the early fuqahā'. It also used arguments derived from qiyās, narratives from the Prophet's companions and hāāith from the Prophet itself. Further, while explicating the issue of small congregators in Friday prayer, Tok Pulau Manis also cited Kitab Munyatu Ahli al-Wara' by Syeikh Ahmad al-Qushashi (d. 1661M) (Shafie, 1985).

\subsection{Risalah Kayfiyyah Niyyah}

Just like Risalah al-Naql, the third fiqh write up by Tok Pulau Manis is also a brief chapter of 17-pages. It was named Risalah Kayfiyyah al-Niyyah. It focuses on the way of niyyat (evoking one's intention) while performing ibadat (worship). According to 'Dutch Catalogue of Malay Manuscripts' by published by Het Museum van het Bataviaasch Genootschapvan Kunst en Wetenschappen in Batavia, Java, a copy of Risalah Kayfiyyah al-Niyyah was found at the end of Hikam Melayu book. This discovery proves that this risalah was utilised outside Terengganu (Shafie, 1984).

Tok Pulau Manis wrote Risalah Kayfiyyah Niyyah based on his teacher's book 'A'māl al-Fikri wa Rawiyyatu' and 'Miftāḥ al- 'Ulā' by Syeikh Aḥmad Ibn 'Ațā'illāh. Miftāḥ al- 'Ulā was an excerpt from Iḥyā' 'Ulūm al-Dīn by al-Imām al-Ghazālī. This book contains the discussion on niyyah as a central theme in any ibadat (Ismail, 2012 \& Shafie, 1984).

\section{Fiqh Writings of Tok Pulau Manis: A Legacy that Lives on}

After the demise of Tok Pulau Manis in 1736AD, fiqh writings mainly centre on reproduction of the currently available books. For example, Kitab al-Kifāyah was reproduced by Ali bin Qadhi Haji Muhammad Salih Fatani which hailed from Pattani but was later relocated to Terengganu. In a copy of Kitab al-Kifāyah, it was recorded that he had finished his reproduction of the book in 1282H (Shafie, 1977). Reproduction work has started earlier but there was no official record of the copier. After the demise of Tok Pulau Manis, classical scholars from Terengganu have managed to continue his work. In $1891 \mathrm{AD}$, a fiqh book entitled Risālah FïBayān Hukm al-Bay’ 
wa al-Riba $\bar{a}$ was written by Syeikh Abdul Qadir bin Abdul Rahim Bukit Bayas. He was born in Pattani circa 1790s (Omar, 1991) but resided in Bukit Bayas, Kuala Terengganu for almost 32 years (Hasanuldin, 2014). This book discusses on the issue of fiqh muamalat with specific reference to ribā (usury). He no longer discusses on the issues that was extensively covered by Tok Pulau Manis. Then, fiqh writings was continued by Sayyid Muhammad bin Zayn al- ${ }^{\mathrm{C}}$ Abidin or more popularly known as Tokku Tuan Besar (1795-1878AD). According to Abdul Razak (2012), Tokku Tuan Besar has managed to write two fiqh writings, i.e. Sullam al-Taufiq and Tuhfat al-Wildān. Sullam al-Taufīq comprises of 6-pages and explicates on the questions of muafiq and masbuq in congregational prayers. Tuhfat al-Wildān however, was written in poetry-style on the same subject. Another fiqh writing by Tokku Tuan Besar is called Kitab al-Mukhtașar. The book was introduced by Wan Mohd Saghir Bin Abdullah (2000). Apart from reproduction works, writings on fiqh subject were on the rise. Another scholar that was contemporaneous with Tokku Tuan Besar is Tok Ku Melaka. He was also a fellow statesman of Tok Pulau Manis. He wrote two books on fiqh, i.e. Hidāyah al- Awām fì Bayān Hukm Syarb al-Dukhān and Targhīb al-Rijāl fì Kasb al-Halāl (Saghir, 2000).

\section{Conclusion}

Findings from this study show that Tok Pulau Manis is a classical scholar that has brought about change to the lives of Muslims in the Malay Peninsula, especially in Terengganu. He institutionalised pondok system in Terengganu has not only provides a place to study the religion for the locals but people outside Terengganu too. His deep understanding of the religion has attracted the attention of the ruler at that time, Sultan Zainal Abidin I to appoint him as the Royal Advisor on matters pertaining to Islam. The Sultan was able to solve various issues with the advice of Tok Pulau Manis. His contribution by means of his writings especially through Kitab al-Kifayah, Risalah al-Naql and Risalah Kayfiyyah al-Niyyah has clarified the rulings that affected the people of that time. His writings have put him as a pioneer of fiqh writings in the Malay Peninsula.

\section{References}

Abdul Kadir, M. (1996). Sejarah Penulisan Hukum Islam di Malaysia [The History of Islamic Rulings in Malaysia]. Kuala Lumpur: Dewan Bahasa dan Pustaka.

Azyumardi, A. (1994). Jaringan Ulama Timur Tengah Dengan Kepulauan Nusantara Abad XVII dan XVIII [The Network of Scholars in the Middle East and Malay Archipelago between XVII and XVIII centuries]. Bandung: Penerbit Mizan.

Hasanulddin, M. (2014). Kitab Risālah F̄̄ Bayān Ḥukm al-Bay’ wa al-Ribā Karangan Syeikh Abdul Qadir Bin Abdul Rahim Bukit Bayas: Kajian Teks dan Maslahah [Kitab Risālah F̄̄ Bayān Ḥukm al-Bay’ wa al-Ribā by Syeikh Abdul Qadir Bin Abdul Rahim Bukit Bayas: Studies on the Textual and Public Interest]. (Doctoral thesis, Islamic Studies Academy, Universiti Malaya, Kuala Lumpur).

Ibrahim, M. (2009). Manaqib Tok Pulau Manis Syeikh Abdul Malik bin Syarif Abdullah. Terengganu: Ikatan Pengkajian Tauhid Tasawuf.

Ismail bin Embong ( $8^{\text {th }}$ generation of Syeikh Abdul Malik bin Abdullah). Interview on 1st February 2011.

Ismail. C. D. (2012). Tokoh-tokoh Ulama'Semenanjung Melayu (1), [Islamic scholars of the Malay Peninsula]. Kelantan: Majlis Agama Islam dan Adat Istiadat Melayu Kelantan.

Kitab al-Kifayah. IAMM 1998.1.179. Islamic Arts Museum Malaysia.

Kitab al-Kifayah. MS 517. National Library of Malaysia.

Kitab al-Kifayah. MSS 1897. National Library of Malaysia.

Mahayudin, Y. (n. d.). Karya Klasik Melayu Islam [Classical work of Malay Muslims]. (Kuala Lumpur: Dewan Bahasa dan Pustaka, 2000).

Mohammad Redzuan, O. (1998). The Role of Makka-Educated Malays in the Development of Early Islamic Scholarship And Education In Malaya. Journal of Islamic Studies, 9(2).

Mohd Saleh, A. (1983). "Perkembangan Penulisan dan Pengarang-pengarang Terengganu sebelum Perang Dunia Kedua" [Writing development and Terengganu writers before World War II] in Mohd Salleh bin Awang \& Mohd Yusoff bin Abdullah (ed.) PESAKA (Monograf Lembaga Muzium Negeri Terengganu), Lembaga Muzium Negeri Terengganu: Terengganu.

Shafie A. B. (1977). Institusi Syeikh Abdul Malik bin Abdullah: Corak Pengajian Tradisi di Terengganu dan Kitab-kitab Padanya [Syeikh Abdul Malik bin Abdullah: Traditional learning institution in Terengganu and its books]. (Master thesis, Universiti Kebangsaan Malaysia). 
Shafie A. B. (1984). Syeikh Abdul Malik bin Abdullah dan Karangan-karangannya [Syeikh Abdul Malik bin Abdullah and his writings] in Mohd Salleh bin Awang \& Mohd Yusoff bin Abdullah (ed.). PESAKA II (Monograf Lembaga Muzium Negeri Terengganu II). Lembaga Muzium Negeri Terengganu: Terengganu.

Shafie A. B. (1985). Risālah Naql Syeikh Abdul Malik bin Abdullah Dengan Anotasi [Syeikh Abdul Malik bin Abdullah's Risālah Naql with its annotations] in Mohd Salleh bin Awang \& Mohd Yusoff bin Abdullah (ed.), PESAKA III (Monograf Lembaga Muzium Negeri Terengganu).

Shafie A. B. (1989). "Sheikh Abdul Malik bin Abdullah (Tuk Pulau Manis)", WARISAN, (Jurnal Persatuan Sejarah Malaysia Cawangan Terenggganu) (Vol. 5). Terengganu: Persatuan Sejarah Malaysia Cawangan Terengganu.

Sheppard, M. C. ff. (1949). A History of Terengganu. Vol XXII. Part III. Jun.

Tok Pulau Manis (1650-1736M). Retrieved from http:/Islaminus.blogspot.com/2009/06/

Tuan Guru Sheikh Tok Ku Ibrahim Mohamad, Principal of Pondok Pulau Manis ( $8^{\text {th }}$ generation of Syeikh Abd Al-Malik bin Abdullah), Kampung Pulau Manis, Kuala Terengganu. Interview on 15th January 2011.

Zurita, M. Y. (2014), Kitab al-Kifāyah Karangan Syeikh Abdul Malik bin Abdullah: Teks dan Analisis [Kitab al-Kifāyah by Syeikh Abdul Malik bin Abdullah: Texts and Analysis]. (Doctoral thesis, Islamic Studies Academy, Universiti Malaya, Kuala Lumpur).

\section{Notes}

Note 1. The literal translation of 'Serambi' in Malay is 'gateway'. 'Serambi Mekah' therefore means 'gateway of Mecca'

Note 2. 'Tarīqah' is a term for a school of Sufism. It involves mystical teachings and spiritual practices with the aim of seeking the 'ultimate truth'.

Note 3. Pondok literally means 'cottage'. The common practice is for the students to build small huts known as "pondok" around the vicinity of the mosque or the teacher's home during the entire study. The main objective of the pondok school is 'to instruct and emphasise the foundations of Islam and its religion practices' (Yong Zhao, Jing Lei, Guofang Li, Ming Fang He, Kaori Okano, Nagwa Megahed, David Gamage, Hema Ramanathan, 2010).

\section{Copyrights}

Copyright for this article is retained by the author(s), with first publication rights granted to the journal.

This is an open-access article distributed under the terms and conditions of the Creative Commons Attribution license (http://creativecommons.org/licenses/by/3.0/). 